\title{
Cervical Adenomyoma
}

National Cancer Institute

\section{Source}

National Cancer Institute. Cervical Adenomyoma. NCI Thesaurus. Code C40231.

A rare, benign, usually polypoid neoplasm that arises from the cervix. It is characterized by the presence of a glandular component and a smooth muscle cell component.

Variants include the endocervical type, endometrial type, and atypical polypoid adenomyoma. 